\title{
Description of the use of integrative mixed method in neonatal nursing
}

\author{
Descrição do uso do método misto integrativo na enfermagem neonatal \\ Descripción del uso del método mixto integrador en la enfermería neonatal
}

Claudia Silveira Viera ${ }^{1}$, Bruna Maria Bugs ${ }^{1}$, Ariana Rodrigues Silva Carvalhoo ${ }^{2}$, Maria Aparecida Munhoz Gaiva ${ }^{3}$, Beatriz Rosana Gonçalves de Oliveira Toso ${ }^{1}$

How to cite this article:

Vieira CS, Bugs BM, Carvalho ARS, Gaiva MAM, Toso BRGO. Description of the use of integrative mixed method in neonatal nursing. Rev Esc Enferm USP. 2019;53:e03408. DOI: http://dx.doi.org/10.1590/S1980-220X2017039303408

${ }^{1}$ Universidade Estadual do Oeste do Paraná, Programa de Pós-Graduação de Biociências e Saúde, Cascavel, PR, Brazil.

${ }^{2}$ Universidade Estadual do Oeste do Paraná, Colegiado de Enfermagem, Cascavel, PR, Brazil.

${ }^{3}$ Universidade Federal do Mato Grosso,

Faculdade de Enfermagem, Cuiabá, MT, Brazil.

\begin{abstract}
To describe the application of the integrative mixed method and its steps. Descriptive methodological study. The integrative mixed method approach was exemplified in a study conducted in neonatal nursing on maternal stress throughout the experience of premature newborns' care. Data on maternal stress level (quantitative approach) and maternal perception of care (qualitative approach) were grouped after analyzes made separately according to the analysis technique of each approach. Subsequently, quantitative and qualitative data were integrated, which originated a new set of data to be interpreted, and consequently enabled a greater understanding of the phenomenon under study and emphasized the importance of the integrative mixed method. The integration of the two approaches, qualitative and quantitative, is a denser theoretical framework with strong scientific evidence for a better understanding of the phenomenon under study than the use of a single approach, since, at the same time, it identifies the frequency of the phenomenon and the reason for its occurrence.
\end{abstract}

\section{DESCRIPTORS}

Neonatal Nursing; Nursing Research; Methodology; Qualitative Research; Quantitative Research. 


\section{INTRODUCTION}

The mixed-method approach is a recent methodology in the health sciences, since it came from the social sciences, when it was introduced in the 1960s, and has been considered the third methodological movement ${ }^{(1)}$. This research methodology proposes the systematic integration between quantitative and qualitative data in the same study ${ }^{(2)}$. This approach differs from the usual data triangulation, in which the association of more than one method or research technique is used to obtain and analyze data. A mixed-method study does not mean conducting two separate studies on a particular issue, but employing different methods to address a specific research question or hypothesis of each approach in a same study ${ }^{(1)}$.

The basic premise in the mixed method is that articulation between qualitative and quantitative methods allows complete synergy in use of data, which is different if they are analyzed separately, even if discussed together. The choice of this method should occur when data of a single approach are not sufficient to apprehend the object under study; when the results need further explanation; in the need to explore the findings to be generalized; or when the complexity of research objectives is best served by multiple phases or types of data ${ }^{(3)}$.

Research using mixed methods is focused on the strengths of qualitative and quantitative approaches by combining both components into a single study in order to increase the scope and depth of understanding of the topic ${ }^{(2)}$. Therefore, the mixed method is particularly used for understanding contradictions between qualitative and quantitative findings. In this research modality, as for all others, the object needs to be well delineated by pointing the focus of the qualitative and quantitative study through questions and hypotheses.

This type of research reflects participants' point of view and proposes a flexible methodology adapted to different types of studies, such as observational and randomized clinical trials. Thus, more information can be elucidated than if using only one of the approaches ${ }^{(3)}$.

Given the aforementioned definition and the possibility of wide use of the mixed method in research in different health contexts $^{(4-5)}$, as it allows the union of a qualitative and quantitative study by encompassing broader perspectives on the same phenomenon, this method should be disseminated to nursing in order that researchers can appropriate and apply it to their objects of study. Thus, the aim is to describe the application of the integrative mixed method and its steps.

\section{METHOD}

Descriptive methodological study with the aim of development, validation and evaluation of tools and research methods in order to obtain greater reliability and validity of results $^{(6)}$. Therefore, the use of the integrative method and its steps are described with the example of a study in the area of neonatal nursing.

\section{CONCEPTUALIZING THE METHOD}

The mixed method approach can be classified into two broad categories, namely the sequential and the concurrent.
In the first category, collection of qualitative or quantitative data occurs at an early stage of the study, followed by the collection of the other approach at a second moment. In the concurrent category, the two data are collected at the same time. The two categories have three specific designs, based on the emphasis on qualitative and quantitative data: 1 ) they are treated equally or unequally; 2) the process of data integration is used for the analysis; and 3) if the theoretical basis behind the study methodology promotes social change or social support ${ }^{(4,7)}$.

The sequential mixed method can be developed under three types of study design: exploratory sequential, explanatory sequential and sequential transformative, while the concurrent mixed design types are: concurrent triangulation, concurrent nested, and concurrent transformative ${ }^{(2)}$. One of the characteristics of the mixed method is that collection and analysis of data from both approaches requires the use of a rigorous procedure of the following research steps according to each study: appropriate selection of sample size for each approach; integration of data during data collection, analysis or discussion; use of procedures that implement qualitative and quantitative data concurrently or sequentially with the same sample or with different samples. In addition, the design of procedures should be based on a theoretical-philosophical research model ${ }^{(8)}$.

For the validation of data, the researcher should use the resources indicated by the two approaches and may use a conversion design for comparing the findings from the qualitative and quantitative data sources. To this end, the two types of data should be collected simultaneously and analyzed separately. Their results should be compared side by side in the discussion by transforming the set of qualitative information within quantitative scores or vice versa, or the two forms of data should be presented together ${ }^{(9)}$.

The two types of data can provide the validation from one to the other and create a solid basis for drawing conclusions about the proposed study. Qualitative data can also be used for exploring quantitative findings or the other way around. This exploration has two phases. In the first, is applied the instrument chosen for quantitative research, and the second phase (related to qualitative data collection) must be developed in a coordinated way with findings of the quantitative phase by using the most appropriate instrument to the object of study. This statement is also true for the contrary, i.e., when starting with qualitative research and exploring the same data in a quantitative way ${ }^{(9)}$.

Given the complex objects of study in the health area, it has been difficult to follow the guidelines pointed for the development of the mixed method, since few researches have effectively associated qualitative and quantitative approaches in a unified and totally integrated system from the research project until data analysis, which is called integrative mixed method ${ }^{(10)}$.

In the integrative mixed approach, a central category is constructed or a construct is delineated from a specific theoretical framework. The basis of the design of the integrative mixed method is developed in six steps: 1) 
Parallelism in the development of the study: choice of the study design and definition on how quantitative and qualitative approaches will be adopted, the study must be developed linearly; 2) Compilation of evidence: determining the state of the art of the study object; 3) Conversion of data: after obtaining quantitative and qualitative data, the quantitative data are converted into qualitative codes and vice versa. In a well-designed study, qualitative thematic categories can be converted into numerical thematic variables ${ }^{(11)}$; 4) Data analysis: is performed the isolated analysis of data obtained in the two approaches; 5) Interpretation: discussion of data according to the theoretical framework adopted; and 6) Integration: recontextualization takes place through the conversion of statistically calculated results from the original qualitative context by allowing a rich interpretation of results qualitatively and quantitatively ${ }^{(7,11)}$.

In a total integrative perspective, the main objective is to examine the evidence from research by using both types of data and generating a deep structure that supports the conclusions. Thus, the greater the qualitativequantitative parallelism projected in the study since its inception, the easier it will be to transform, transfer, and interpret forms of textual and numerical data between the two approaches ${ }^{(11)}$.

Recontextualization of data is the true power of research in which the mixed method is adopted. It involves the development of the emerging theory in order that it is applicable to other contexts and populations, starting from the return to the original context, where observations were done by relating the statistical results for selecting citations that will be narrated to give voice to participants. The narrative of statements is used to generate the descriptive history about the central phenomenon under study, thus contributing to a deep analysis of the structure that goes beyond the description or conceptualization of facts ${ }^{(7)}$.

\section{CONTEXTUALIZING DATA COLLECTION IN THE MIXED METHOD}

As an example of the mixed method application, are presented fragments of the study titled 'Stress of premature babies' mothers: the complementarity of the mixed method', approved by the Ethics Committee in Research with Human Beings under number 1,134,712. The primary research was conducted from July 2015 to September 2016 with the objective of identifying maternal stress levels and difficulties in caring for the premature newborn (PNB) at home, and assessing if there was influence of the stress level on maternal perception of care after discharge from the Neonatal Intensive Care Unit (NICU) by the mixed method approach. Then, two research approaches appear in the general objective. The examination of maternal stress level comprised the quantitative approach of the study, and the maternal perception about the care was the qualitative approach of the study. For the qualitative stage, was sought an understanding of maternal perception regarding care with the child after discharge from the NICU.

A sample calculation was made in order to elect the quantitative study sample, and there were 56 participants in total. The subjects of the qualitative stage were selected randomly among these 56 participating mothers, and the closing of collection at this stage followed the precepts of data saturation and reach of the study objectives with the total of 15 subjects.

Quantitative data were collected sequentially in two moments: first, during hospitalization with application of the Parental Stress Scale (PSS: NICU) ${ }^{(12)}$ and collection of secondary data by analysis of medical records for gathering maternal and clinical sociodemographic data of the premature newborn. Then, after hospital discharge, the Parenting Stress Index (PSI) scale ${ }^{(13)}$ was applied to premature infants' mothers during the return visit at the preterm follow-up clinic. With application of these instruments, was obtained data on the profile of mothers and premature infants, as well as the level of maternal stress at hospitalization and after discharge.

Qualitative data were obtained concomitantly with quantitative data by means of an in-depth interview with premature infants' mothers soon after application of PSI at the preterm follow-up clinic three months after discharge from the neonatal unit. The following guiding questions were used during interviews: For you, what is it like to take care of your premature infant after discharge from the NICU? What are your feelings about the experience with the premature infant at home in those early months? Each issue had a road map on topics addressed such as child care, difficulties with the care, fears, anxieties and anguish experienced by the mother after the premature infant's discharge from hospital. Interviews were audio recorded, and the content was validated by participants.

The design of the aforementioned study was the concurrent mixed method, in which qualitative and quantitative data are treated with the same emphasis in both sets of data. The integrative analysis of data was made through connection of the two methods in the data interpretation phase, and the theoretical basis of the study contributed to the emotional support of premature infants' mothers. Given the objective of the study, analyzing only the psychometric scales of measurement of maternal stress levels would provide a one-dimensional view of the phenomenon under study. However, when including the qualitative approach by means of an in-depth interview, is obtained a more complete evaluation of subjects' emotions.

In the integrative mixed method design, the conversion of qualitative and quantitative data should take place from a specific theoretical framework, which, in the exemplified study, was the maternal stress and maternal competence for the care of the premature infant. From these references, was constructed the analysis scheme in the mixed method model, as shown in Chart 1.

In this process, the mixed method was adopted in order to use the data set of the two types of methodological approaches for answering the same question related to the proposed object of study. Thus, from the convergence of data, was made the concurrent triangulation that designates the interpretation of results by comparison for understanding if the same conclusion would be reached. 
Chart 1 - Design of the study of research by mixed method - Cascavel, PR, Brazil, 2016.

\begin{tabular}{|c|c|c|c|c|c|c|}
\hline Approach & \multicolumn{6}{|c|}{ Qualitative } \\
\hline Steps & 1 & 2 & 3 & 4 & 5 & 6 \\
\hline $\begin{array}{l}\text { Theory/ } \\
\text { Categories }\end{array}$ & Design & Collection & Conversion & Analysis & Interpretation & Integration \\
\hline $\begin{array}{l}\text { Category: } \\
\text { adaption of } \\
\text { care }\end{array}$ & $\begin{array}{l}\text { Recorded In- } \\
\text { Depth Interview }\end{array}$ & $\begin{array}{l}\text { Mothers of PNG } \\
\text { in a follow-up } \\
\text { clinic }\end{array}$ & $\begin{array}{l}\text { Category and } \\
\text { Thematic } \\
\text { Variable }\end{array}$ & $\begin{array}{c}\text { Content } \\
\text { Analysis, Matrix } \\
\text { Association }\end{array}$ & $\begin{array}{l}\text { Analysis of } \\
\text { Speeches } x \\
\text { Literature }\end{array}$ & \multirow{3}{*}{$\begin{array}{c}\text { Integrative } \\
\text { Analysis } \\
\text { Drafting } \\
\text { Conclusions }\end{array}$} \\
\hline $\begin{array}{l}\text { Theory: } \\
\text { Stress X Care }\end{array}$ & & & $\begin{array}{c}\text { Scale Code } \\
\text { Analysis of Itens }\end{array}$ & & $\begin{array}{l}\text { Recontextuali } \\
\text { zation }\end{array}$ & \\
\hline $\begin{array}{l}\text { Category: Daily } \\
\text { Care }\end{array}$ & $\begin{array}{l}\text { Parental stress } \\
\text { scale in NICU e } \\
\text { Parenting } \\
\text { stress index } \\
\text { after hospital } \\
\text { discharge }\end{array}$ & $\begin{array}{c}\text { Self-completed } \\
\text { by mothers at } \\
\text { clinic }\end{array}$ & $\begin{array}{l}\text { Scales } \\
\text { Codes }\end{array}$ & $\begin{array}{l}\text { Inferential } \\
\text { Descriptive } \\
\text { Statistics }\end{array}$ & $\begin{array}{l}\text { Interpretation } \\
\text { Model }\end{array}$ & \\
\hline Approach & \multicolumn{6}{|c|}{ Quantitative } \\
\hline
\end{tabular}

Source: adapted from Castro; Kellison; Kopak ${ }^{(7)}$.

\section{DATA ANALYSIS}

Some authors ${ }^{(14)}$ classify the analysis process by the mixed method in seven steps, as follows: 1. Reduction of data (reduce dimensionality of quantitative data and qualitative data); 2. Data visualization (visually describe quantitative and qualitative data); 3. Transformation of data (quantify or qualify data); 4. Correlation of data (correlating quantitative data with quantified data or vice versa); 5 . Data consolidation (combining quantitative and qualitative data in order to create or consolidate a variable or a set of new data); 6. Comparison of data (comparing data from quantitative and qualitative sources) and 7. Integration of data (articulation of qualitative and quantitative data into a coherent whole).

Data analysis in a mixed-method study is complex and requires the researcher's ability for the evaluation of both quantitative and qualitative data and the integration of results arising from quantitative and qualitative analysis "in a coherent and meaningful way that produces strong meta-inferences (inferences from qualitative and quantitative results to be integrated into a coherent whole or two distinct sets of coherent sets)"(14).

Thus, in this descriptive study of application of the mixed method, the evidence generated by data in the application of such a method followed the seven aforementioned steps. Steps 1 and 2 for quantitative data corresponded to the tabulation of data in Excel for Windows 2010, and double checked typing. Then, data were analyzed by descriptive statistics, the characterization variables of the sample were compared with the chi-square test for independence, and in case of statistical significance $(p<0.05)$, frequencies were compared in pairs by using the adjusted residue test. Data were presented descriptively in tables.

The initial steps for qualitative data from in-depth interviews occurred, first, with their transcription. Subsequently, the interviews were imported into the Atlas.ti 7.5.10 program, read exhaustively for extraction of relevant statements on the central issue of the study, and identification of codes by highlighting the relevant citation that responds to the focus of the question and creates the thematic categories. At this time, were inserted several response codes with functionally equivalent meaning to a higher order (hierarchically superior) and related to the family theme/category. A response code can be linked to more than one thematic category and convert these categories into thematic variables. Thus, was made the coding scale, in which a dichotomous category is converted into an ordinal variable. In each thematic category, two or more codes form the coding scale, and are presented descriptively.

Following the individual analysis of each type of data, the quantitative data were qualified by frequency distribution of quantitative variables, description of thematic variables and association of the set of thematic variables, and by correlating these to the set of quantitative data. From then on, data related to categories of interviews were quantified and evaluated in the form of absolute frequencies. This phase comprises the correlation of both data, and is named concurrent triangulation of data.

In order to develop the data consolidation step, the scores of the scales applied were grouped, and the absolute frequencies of each of the thematic categories were distributed in the respective classification levels of data based on scores of the psychometric scales. This new grouping of data was compared using the chi-square test for $\mathrm{k}$ proportions by adopting a significance level of 0.05 . Data were compared to their original sources (qualitative and quantitative). Statistical analyzes were performed in the XLStat 2016 Addinsoft program (2016).

The data integration step was developed with the coordination of quantitative and qualitative data by reaching a coherent whole. From the indicators of an interest-dependent variable, that is, maternal stress in the experience of caring for the premature child, was developed the theoretical construct of the elements delineating the understanding of this phenomenon marked by the frequency of its occurrence and maternal behaviors experienced in the premature infant daily care at home. 


\section{RESULTS}

\section{ReCONTEXTUALiZATION OF DATA IN APPLICATION OF THE MIXED METHOD}

At this moment, data are presented from the convergence of the mixed method with integration of quantitative and qualitative results. An example of the stage of qualitative and quantitative data correlation, is the comparison of stress levels obtained with application of the scales used in the study, and the narratives of participating mothers (Chart 2). By matching data, it was possible to relate the value of the identified stress score and the meaning to mothers through the narratives. This provided a greater understanding of the phenomenon under study and highlighted the meaning of the method, since at this stage occurs the correlation of data itself.

On the other hand, the consolidation of quantitative and qualitative data set was achieved by the convergence of these data from stress level scores measured with the validated scales, in addition to the thematic categories emerging from in-depth interviews (Table 1).
In this process, the mixed method was applied for using the data set of the two types of methodological approaches in order to answer the research question related to the proposed object of study. Thus, complementarity of data was achieved with use of the method, since from convergence of these data, the results were analyzed by comparison in order to check if the same conclusion was reached.

The use of the mixed method enabled the generalization of results from a sample of the population and an in-depth understanding of the object studied. The level of stress during and after hospitalization could be identified, and the maternal perception about the care of premature infants at home could be understood. A combination of activities and feelings was apprehended and, regardless of mothers' level of stress assessed by the scale of stress evaluation during hospitalization or after discharge from the NICU, the reports about adaptation of care at home were similar, and there was no statistically significant difference. Thus, qualitative data confirmed what had already been identified with the measurement through scales.

Chart 2 - Comparison of scores of the scales allocated in the quantitative sample and narratives from in-depth interviews with subjects in the qualitative stage - Cascavel, PR, Brazil, 2016.

\begin{tabular}{|c|c|c|c|c|}
\hline $\begin{array}{c}\text { Scores of } \\
\text { Quantitative variables }\end{array}$ & $\begin{array}{c}\text { Minimum } \\
\text { score }\end{array}$ & $\begin{array}{c}\text { Narratives of interviews } \\
\text { with lower stress score }\end{array}$ & $\begin{array}{c}\text { Maximum } \\
\text { score }\end{array}$ & $\begin{array}{c}\text { Narratives of } \\
\text { interviews with higher stress score }\end{array}$ \\
\hline Scale score & 1 & $\begin{array}{c}\text { The insecurity was in me, of being ugly, } \\
\text { strange, but not when taking care of her (I 7). }\end{array}$ & 5 & $\begin{array}{c}\text { I was very sad when he was } \\
\text { hospalized, because I was alone, } \\
\text { then I was scared, and he didn't put on } \\
\text { weight and sometimes lost weight, this } \\
\text { made me scared (I3). }\end{array}$ \\
\hline
\end{tabular}

Table 1 - Description of the convergence of quantitative and qualitative data through frequencies of thematic categories in the interviews according to ratings from the score of the scale used in the quantitative stage - Cascavel, PR. Brazil, 2016.

\begin{tabular}{|c|c|c|c|c|c|c|c|}
\hline \multirow[t]{2}{*}{ Thematic categories } & \multirow[t]{2}{*}{ Defining codes } & \multicolumn{2}{|c|}{$\begin{array}{l}\text { Levels of scores } \\
\text { Hospitalization scale }\end{array}$} & \multirow[t]{2}{*}{$\mathbf{p}^{*}$} & \multicolumn{2}{|c|}{$\begin{array}{c}\text { Levels of scores } \\
\text { post-hospital discharge }\end{array}$} & \multirow[t]{2}{*}{$\mathbf{p}^{*}$} \\
\hline & & 1 a 3 & 4 a 5 & & 1 a 50 & 51 a 100 & \\
\hline \multirow{6}{*}{$\begin{array}{l}\text { Thematic category } \\
\text { emerging from } \\
\text { qualitative analysis }\end{array}$} & Dificulty with care & $7(100 \%)$ & $7(88 \%)$ & 0.333 & $7(88 \%)$ & $7(100 \%)$ & 0.333 \\
\hline & Concern & $4(57 \%)$ & $6(75 \%)$ & 0.464 & $4(50 \%)$ & $6(86 \%)$ & 0.143 \\
\hline & Nervousness & $5(71 \%)$ & $7(88 \%)$ & 0.438 & $5(63 \%)$ & $7(100 \%)$ & 0.070 \\
\hline & Anguish & $3(43 \%)$ & $4(50 \%)$ & 0.782 & $3(38 \%)$ & $4(57 \%)$ & 0.447 \\
\hline & Anexiety & $6(86 \%)$ & $8(100 \%)$ & 0.268 & $7(88 \%)$ & $7(100 \%)$ & 0.333 \\
\hline & Sadness & $4(57 \%)$ & $0(0 \%)$ & 0.013 & $2(25 \%)$ & $2(29 \%)$ & 0.876 \\
\hline
\end{tabular}

*p-value of test applied by inferential statistical analysis.

\section{DISCUSSION}

In Brazil, and specifically in relation to neonatal nursing, the use of integrative mixed method is not usual. In addition, the experiments found refer to international studies ${ }^{(15-17)}$. Since in this methodological approach the researcher collects and analyzes data by integrating the findings into a single study, the integrative method was not developed in all international studies analyzed. Some studies exposed the results of the data set found in qualitative and quantitative approaches in a dichotomized way, and in the analysis was presented the comparison of findings without the convergence step.

Among other advantages, the development of studies adopting the mixed method can be used with different study designs and for comparing quantitative and qualitative data, which allows the understanding of contradictions between the results of these two approaches. Moreover, it provides rich and comprehensive data in both approaches, which integrated, generate a more complete analysis than the isolated use of one of the methods. Thus, the subjects of quantitative research gain a voice in the qualitative approach ${ }^{(8)}$. 
One of the main reasons for using the mixed method is the possibility of triangulation analysis. It allows greater efficiency in a study by seeking the corroboration between quantitative and qualitative data. The phenomenon under study can be apprehended in its entirety, since the combination of research approaches leads to a more complete and comprehensive view of the phenomenon in question ${ }^{(1,18)}$.

This method can also compensate the weaknesses of the study and provide more compelling inferences as it allows the neutralization of limitations in each approach, while building strengths in a more robust and accurate manner. In this type of approach, different research questions can be answered, i.e., elucidate doubts that cannot be clarified by a single approach separately. Furthermore, a larger repertoire of data is provided in order to meet the goals and objectives of the study ${ }^{(10,19)}$.

Research in which the mixed method is used may have more practical benefits in terms of attracting funding for the study ${ }^{(20)}$, since funding agencies have sought interdisciplinary projects involving different knowledge and professionals, such as studies conducted between nursing, medicine, dentistry, nutrition, anthropology, sociology. Different visions of research are involved in this type of composition, from a more positivist view to a more complex view of men and their health, for example.

In order to work in interdisciplinary research in this context, using the mixed method is fundamental, since those involved can contribute with their different visions and build a unique knowledge by contemplating quantitative and qualitative aspects. The combination of different research approaches is useful in areas such as nursing because, given the complex nature of phenomena and the range of points of view needed, this method contributes to answer the questions raised.

In the area of health in general, the choice of the mixed method approach as a study methodology has the aim to provide concrete data for decision making. Therefore, this method can determine health care policies, since, in addition to identifying health needs, it offers an understanding of the context in which such data coexist ${ }^{(4)}$. For nurses in particular, this approach allows a broader view of the health/ disease process by considering other analyzes, especially historical-cultural analyzes since, besides identifying clinical and epidemiological characteristics about the phenomenon under study, it shows its subjectivity. However, in Brazilian nursing, which includes neonatal nursing, the use of this type of approach in research is still scarce ${ }^{(21)}$.

This method also allows new insights and perspectives of understanding phenomena in nursing research. In the study presented as an example, on mothers' stress during the stay of the premature infant in the NICU and after discharge from this unit, high levels of stress were observed during hospitalization, but they reduced throughout the newborn's follow-up. Only the application of psychometric scales would not allow the understanding of the reason for stress reduction after discharge. The in-depth interview brought the perception of protective elements that contributed to maternal security and the development of healthy maternal competence, even in the face of a premature child. Therefore, the mixed method research allows the identification of themes and issues emerging from data integration that indicate greater proximity to the phenomenon investigated ${ }^{(4)}$.

The development of integrative mixed research requires more time for data collection and data analysis than when using only one of these approaches. This fact associated with the intolerance of qualitative researchers in discussing from a quantitative analysis and vice versa ${ }^{(3)}$, sometimes discourage the use of the mixed method, or even leads to the perception that using it is a challenge to the current research orthodoxy.

Research with mixed method involves not only the joint use of qualitative and quantitative data, but their integra$\operatorname{tion}^{(22)}$. However, this integration is the weakest link in most studies of mixed methods ${ }^{(22)}$, so the challenge lies in clearly defining what each approach adds to knowledge ${ }^{(23)}$ with the aim of a more in-depth vision about the subject or phenomenon under study.

\section{FINAL CONSIDERATIONS}

The application of the mixed method in neonatal nursing research is useful because it offers the deepening of issues identified as problems of clinical or epidemiological study. However, only its quantification or description would not suffice, the thematic must be deepened in order to understand subjectivities, which is possible through the qualitative approach. In addition, the integration of both approaches consolidates a theoretical framework of greater density with strong scientific evidence, since the new data set generated by the integration is tested, and the inferences of the two approaches are interpreted together.

Research questions involving stress and the experience of care tend to be abstract, which often indicates limitation in their assessment as a whole. In this context, is required the development of an integrated qualitative and quantitative approach that goes beyond the description of the use of different data sources or data collection methods. The integrative mixed method adopted in this study served the purpose of explaining the initial results in greater depth, and showed the convergence of qualitative data with quantitative data. Also, the application of the mixed method in the research example added information that could go unnoticed in a dimensional evaluation.

In sum, by combining quantitative and qualitative data in the same study, researchers can benefit from the strengths of each approach in order to reduce their deficiencies. In practice, this effort facilitates investigations by researchers in health science, given the complex and multifactorial nature of human health and the disease process.

The application of the mixed method showed the main function of this type of study, which is to ensure that results are not dependent on the modality chosen for research nor on data collection techniques, but the integration should maximize the quantity of information in the study design by generating improvement and raising the quality of research findings.

The following aspects are considered as limitations of the use of the mixed method approach: time, as the need to 
develop qualitative and quantitative approaches sequentially or concurrently makes the data collection process more time consuming; the difficulty to conduct the study only by one researcher; the need for the researcher's experience in both approaches, of having training in the different methods, ability to combine each of them effectively, and also having the will to work with a larger set of data from two distinct ways of obtaining data.
Another challenge to be overcome is maintaining methodological rigor in both approaches. The barriers for implementation of this method are another limitation, since a careful planning is required, and all aspects of the research must be described, including the sample selection of qualitative and quantitative studies, the sequence of development of the approaches and integration of data, which is considered as a difficult phase.

\section{RESUMO}

Descrever a aplicação do método misto integrativo e suas etapas. Estudo metodológico descritivo. A abordagem do método misto integrativo é exemplificada em investigação realizada na enfermagem neonatal, sobre o estresse materno na vivência do cuidado ao recém-nascido prematuro. Dados do nível de estresse materno (abordagem quantitativa) e da percepção materna acerca do cuidado (abordagem qualitativa) foram agrupados depois de terem sido analisados separadamente, conforme a técnica de análise própria de cada abordagem. Na sequência, integraram-se os dados quantitativos e qualitativos, originando novo conjunto de dados a ser interpretado, o que possibilitou aumentar a compreensão do fenômeno em estudo e evidenciar a importância do método misto integrativo. A integração das duas abordagens, qualitativa e quantitativa, constitui-se em arcabouço teórico de maior densidade e com evidências científicas contundentes para melhor compreensão do fenômeno em estudo, do que o uso de uma abordagem única, visto que identifica, ao mesmo tempo, a frequência do fenômeno e o porquê de sua ocorrência.

\section{DESCRITORES}

Enfermagem Neonatal; Pesquisa em Enfermagem; Metodologia; Pesquisa Qualitativa; Pesquisa Quantitativa.

\section{RESUMEN}

Describir la aplicación del método mixto integrador y sus etapas. Estudio metodológico descriptivo. El abordaje del método mixto integrador se ejemplifica en investigación realizada en la enfermería neonatal, sobre el estrés materno en la vivencia del cuidado al recién nacido prematuro. Datos del nivel de estrés materno (abordaje cuantitativo) y la percepción materna acerca del cuidado (abordaje cualitativo) fueron agrupados después de habérselos analizado aisladamente, conforme a la técnica de análisis propio de cada abordaje. A continuación, se integraron los datos cuantitativos y cualitativos, originando nuevo conjunto de datos a interpretarse, lo que posibilitó aumentar la comprensión del fenómeno en estudio y evidenciar la importancia del método mixto integrador. La integración de ambos abordajes, cualitativo y cuantitativo, se constituye en andamiaje teórico de mayor densidad y con evidencias científicas contundentes para mejor comprensión del fenómeno en estudio que el uso de un abordaje único, visto que identifica, a la vez, la frecuencia del fenómeno y la razón de su ocurrencia.

\section{DESCRIPTORES}

Enfermería Neonatal; Investigación en Enfermería; Metodología; Investigación Cualitativa; Investigación Cuantitativa.

\section{REFERENCES}

1. Jirojwong S, Johnson M, Welch A. Research methods in nursing and midwifery. Sydney: Oxford University Press; 2014.

2. Creswell JW. Qualitative inquiry and research design: choosing among five approaches. Thousand Oaks: Sage; 2012.

3. Wisdom JP, Cavaleri MC, Onwuegbuzie AT, Green CA. Methodological reporting in qualitative, quantitative, and mixed methods health services research articles. Health Serv Res [Internet]. 2012 [cited 2016 Aug 10];47(2):721-45. Available from: https://www.ncbi.nlm.nih. gov/pmc/articles/PMC3419885

4. Zubairu K, Christiansen A, Kirkcaldy A, Kirton JA, Kelly C, Simpson P, et al. An evaluation of National Health Service's (NHS) Care Maker Programme: a mixed methods analysis. J Clin Nurs. 2017;26(23-24):4634-45.

5. Eirik A, Gudrun R, Sveinung B, Tonje H. Fun, influence and competence: a mixed methods study of prerequisites for high school students participation in physical education. BMC Public Health [Internet]. 2017 [cited 2017 Apr 18];17(1):241. Available from: https://www.ncbi. nlm.nih.gov/pmc/articles/PMC5345206/

6. Lima DVM. Research design: a contribution to the author. Online Braz J Nurs [Internet]. 2011 [cited 2017 Apr 22];10(2). Available from: http://www.objnursing.uff.br/index.php/nursing/article/view/3648/pdf_1

7. Castro FC, Kellison JG, Kopak A. A methodology for conducting integrative mixed methods research and data analyses. J Mix Methods Res [Internet]. 2010 [cited 2016 Aug 5]; 4(4):342-360. Available from: https://www.ncbi.nlm.nih.gov/pmc/articles/PMC3235529/pdf/ nihms-248033.pdf

8. Wisdom JP, Creswell JW. Mixed methods: integrating quantitative and qualitative data collection and analysis while studying patientcentered medical home models. Rockville: Agency for Healthcare Research and Quality; 2013.

9. Palinkas LA, Aarons GA, Horwitz S, Chamberlain P, Hurlburt M, Landesverk J. Mixed methods designs in implementation research. Adm Policy Ment Health [Internet]. 2011 [cited 2016 Jul 30]; 38(1):44-53. Available from: https://www.ncbi.nlm.nih.gov/pmc/articles/ PMC3025112/

10. Badran H, Pluye P, Grad R. When educational material is delivered: a mixed methods content validation study of the information assessment method. JMIR Med Educ. 2017 [Internet]. 2017 [cited 2017 Apr 22];3(1):e4. Available from: https://www.ncbi.nlm.nih.gov/pmc/articles/ PMC5373673/

11. Castro FG, Coe K. Traditions and alcohol use: a mixed methods analysis. Cultur Divers Ethnic Minor Psychol [Internet]. 2007 [cited 2016 Feb 17];13(4):269-84. Available from: https://www.ncbi.nlm.nih.gov/pmc/articles/PMC3235530/ 
12. Souza SR, Dupas G, Balieiro MMFG. Adaptação cultural e validação para a língua portuguesa da Parental Stress Scale: Neonatal Intensive Care Unit (PSS:NICU). Acta Paul Enferm [Internet]. 2012 [citado 2016 mar. 26];25(2):171-6. Disponível em: http://www.scielo.br/pdf/ape/ v25n2/a03v25n2.pdf

13. Pereira LM, Viera CS, Toso BRGO, Carvalho ARS, Bugs BM. Validação da escala Índice de Estresse Parental para o português do Brasil. Acta Paul Enferm [Internet]. 2016 [citado 2016 dez. 10];29(6):671-7. Disponível em: http://www.scielo.br/pdf/ape/v29n6/1982-0194ape-29-06-0671.pdf

14. Onwuegbuzie AJ, Combs JP. Data analysis in mixed research: a primer. Int J Educ [Internet]. 2010 [cited 2016 Set 26];3(1):E13. Available from: http://www.macrothink.org/ije

15. Lyndon A, Jacobson CH, Fagan KM, Wisner K, Franck LS. Parents' perspectives on safety in neonatal intensive care: a mixed-methods study. BMJ Qual Saf [Internet]. 2014 [cited 2016 July 25];23(11):902-9. Available from: https://www.ncbi.nlm.nih.gov/pmc/articles/PMC4198474

16. Povee K, Roberts L, Bourke J, Leonard H. Family functioning in families with a child with Down syndrome: a mixed methods approach. J Intellect Disabil Res. 2012;56(10):961-73.

17. Branson, D, Dermchak MA. Toddler teachers' use of teaching pyramid practices [abstract]. Topics Early Childhood Spec Educ. 2011;30(4):196-208.

18. Guetterman TC, Fetters MD, Creswell JW. Integrating quantitative and qualitative results in health science mixed methods research through joint displays. Ann Fam Med [Internet]. 2015 [cited 2017 Apr 19];13(6):554-61. Available from: https://www.ncbi.nlm.nih.gov/pmc/articles/ PMC4639381

19. Creswell JW, Klassen AC, Plano Clark VL, Smith Research. Best practices for mixed methods research in the health sciences [Internet]. Washington: National Institutes of Health; 2011 [cited 2016 July 25]. Available from: https://obssr.od.nih.gov/training/online-trainingresources/mixed-methods-research/

20. Kaur M. Application of mixed method approach in public health research. Indian J Community Med [Internet]. 2016 [cited 2017 Apr 21];41(2):93-7. Available from: https://www.ncbi.nlm.nih.gov/pmc/articles/PMC4799647/

21. Santos JLG, Erdmann AL, Meirelles BHS, Lanzoni GMM, Cunha VP, Ross R. Integrating quantitative and qualitative data in mixed methods research. Texto Contexto Enferm [Internet]. 2017 [cited 2018 Apr 08];26(3):e1590016. Available from: http://www.scielo.br/scielo. php?script=sci_arttext\&pid=S0104-07072017000300330\&lng=en

22. Schoonenboom J, Burke Johnson R. How to construct a mixed methods research design. Kolner Z Soz Sozpsychol [Internet]. 2017 [cited 2018 Apr 08];69 Suppl 2:107-31. Available from: https://www.ncbi.nlm.nih.gov/pmc/articles/PMC5602001/

23. Boeije $H$, Slagt $M$, van Wesel $F$. The contribution of mixed methods research to the field of childhood trauma: a narrative review focused on data integration. J Mixed Methods Res. 2013;7(4):347-69. 